\title{
'Little Rascals' or Not-So-Ideal Victims: Dealing with minors trafficked for exploitation in criminal activities in the Netherlands
}

\author{
Brenda Oude Breuil
}

\begin{abstract}
Trafficking in minors for exploitation in criminal activities is a form of human trafficking that is generally not well-recognised and understood by frontline actors. This paper, based on empirical data from frontline actors, shows that this is also the case in the Netherlands. Moreover, the Dutch ethnicised understanding of the phenomenon, which is conceptualised as a 'Roma' problem, further obfuscates the identification of these trafficking cases, leading to a blind spot for victims of other ethnicities and differential treatment of itinerant 'Roma' victims compared to Dutch and resident victims. It also shows that there is a gender bias among frontline workers, with girls being more readily perceived as victims than boys, and interventions in the girls' cases geared towards protection, whereas boys were seen as 'little rascals' that should be punished. The paper concludes that a focus on indicators of the phenomenon, rather than on victim profiles, could improve this situation and help frontline actors take more transparent as well as ethnic- and gender-neutral decisions.
\end{abstract}

Keywords: child, trafficking, exploitation in criminal activities, victim identification, exploitation of minors, frontline actors

Please cite this article as: B Oude Breuil, “Little Rascals” or Not-So-Ideal Victims: Dealing with minors trafficked for exploitation in criminal activities in the Netherlands', Anti-Trafficking Review, issue 16, 2021, pp. 86-103, https://doi. org/10.14197/atr.201221166

This is an open-access article distributed under the terms of the Creative Commons Attribution License (CC-BY). Under the CC-BY license, the public is free to share, adapt, and make commercial use of the work. Users must always give proper attribution to the authors and the Anti-Trafficking Review. 


\section{Introduction}

Several years ago, Milan and Krizstián, two French-speaking boys aged 12 and 14, were arrested by the Dutch police in a posh neighbourhood. ${ }^{1}$ They were suspected of having burglarised a villa, and apprehended after one of them tossed away a glove filled with jewellery during the chase. A few moments earlier, a car with a Bulgarian number plate was stopped in that same neighbourhood, following a burglary report. The driver had burglary tools in his trunk. He claimed that he had given the boys a ride, but that he did not know them; the boys said the same. This, however, was clumsily refuted by the driver's son when the latter made a concerned call to the police requesting information on 'his father and his two nephews', after they were taken into custody.

Forensic work on the car enabled the police to connect the boys to the car and prove their exploitation by the driver, aka their (supposed) uncle. The 'uncle' was tried and convicted of trafficking the two boys for the purpose of exploiting them in criminal activities - but not before the boys had both been detained in a youth facility for four and six weeks, respectively, as a punishment for the crime they committed. According to the Child Protection Board file meant to inform the judge on Milan's backgrounds and advise 'in the best interest of the child':

'Considering the criminal offence, the situation of [Milan], the suspicions of human trafficking, his age and circumstances, the Child Protection Board deems detention in a youth facility most fit. [Milan] should realise that he is not allowed to commit criminal offences and that this behaviour has consequences. ${ }^{2}$

This case, retrieved from our research on exploitation of minors in criminal activities in the Netherlands, ${ }^{3}$ reveals that the road to ensuring 'the best interests of the child' in cases of minors trafficked for exploitation in criminal activities is bumpy. International and EU legislations that the Netherlands has ratified

1 For reasons of anonymity, personal names, places, and dates have been deleted or changed.

2 A Bos et al., Uitbuiting van Minderjarigen in de Criminaliteit in Nederland: Onderzoek naar de signalering aanpak en de samenwerking door professionals, Utrecht University, Utrecht, 2016, pp. 57 and 134, https://dspace.library.uu.nl/bitstream/handle/1874/347141/ WODC_rapport_Uitbuiting_van_minderjarigen_in_de_criminaliteit_in_nl.pdf.

3 This research was conducted in 2015-16 by Dr Kim Loyens and Aline Bos MSc of the Utrecht School of Governance, and Dr Veronika Nagy and Dr Brenda Oude Breuil of the Criminology Department of Willem Pompe Institute for Criminal Law and Criminology (both institutes belonging to Utrecht University), with assistance from Tineke Hendriks, Laura van Oploo and Laura van Tilborg. It was commissioned by the Dutch Ministries of Social Affairs and Employment, and of Justice and Security. It combined a governmental approach with criminological and anthropological expertise. See Bos et al. 
state that victims of trafficking should not be held responsible (and thus not be punished) for crimes they were forced to commit. ${ }^{4}$ However, the boy mentioned in the Child Protection Board file was convicted of burglary and spent several weeks in youth detention. Moreover, both the police officer involved in the case, specialised in human trafficking cases, and social workers of the Child Protection Board (hereafter, 'the Board') commented retrospectively that they found this punishment 'deserved' and just.

One may then wonder: if Milan's right not to be punished was not respected when his trafficking had been proven in court, what then to expect from cases that did not even make it to court? How can we explain the punitive reaction of frontline actors ${ }^{5}$ who encounter victims of this crime in their everyday work? Are they well prepared to identify and deal with such cases, and are they aware of the legal regulations? And do they balance criminal justice interests and the need for protection consistently for all victims they encounter?

These issues were at the heart of our research conducted in 2015-16 on trafficking in minors for exploitation in criminal activities in the Netherlands. This form of human trafficking was then relatively unknown in the country ${ }^{6}$ (and beyond, as international studies on trafficking in minors are overshadowed by those on

4 See, Council of Europe Convention on Action against Trafficking in Human Beings, Warsaw, 2005, Art. 26, and Directive 2011/36/EU of the European Parliament and of the Council of 5 April 2011 on preventing and combating trafficking in human beings and protecting its victims, and replacing Council Framework Decision 2002/629/ JHA, Art. 8.

5 By 'frontline actors' I refer here to social actors who, because of their jobs, are the first to encounter minors (possibly) trafficked for exploitation in criminal activities, such as police officers, social workers, Child Protection Board and custody institutions' employees, etc.

6 A van den Borne and $\mathrm{K}$ Kloosterboer, Inzicht in Uitbuiting. Handel in minderjarigen in Nederland nader onderzocht, ECPAT Nederland, Amsterdam, September 2005, https:// www.politieacademie.nl/kennisenonderzoek/kennis/mediatheek/PDF/03-15057. pdf; M Kaandorp and M Blaak, Kinderhandel in Nederland: De aanpak, van kinderbandel en de bescherming van minderjarige slachtoffers in Nederland, UNICEF \& Defence for Children, May 2013, https://www.unicef.nl/files/kinderhandel_in_nederland_mei_2013. pdf; V Brotherton et al., Trafficking for Forced Criminal Activities and Begging in Europe, Anti-Slavery International, 2014, p. 6, http://www.antislavery.org/wp-content/ uploads/2017/01/trafficking_for_forced_criminal_activities_and_begging_in_ europe.pdf; I De Witte and M T Pehlivan, Vulnerability of Bulgarian and Romanian Children to Trafficking in The Netherlands and in Brussels, Defence for Children \& ECPAT Nederland, Budapest, December 2014, https://www.kis.nl/sites/default/files/ bestanden/Publicaties/Vulnerability-bulgarian-romanian-children-to-trafficking.pdf. The latter reported about 20 cases in Rotterdam between 2010 and 2013 of petty crime committed by Central and East European children in which exploitation was suspected. 
trafficking for sexual and, to a lesser extent, labour exploitation). Back then, only five cases had been successfully tried in court. Besides these five proven cases, there were several 'soft signals' on potential cases of trafficking in minors for exploitation in criminal activities, coming from frontline actors, in particular a custody institution specialised in the care for 'Roma"7 children, and the occasional police officer or social worker who had, rather haphazardly, taken an interest in this group of victims. These potential (mostly 'Roma') cases never made it to court-oftentimes they did not even enter the legal system tout court, and therefore could not be established as proven cases. With 'hard facts' being largely absent, and 'soft signals' having never been systematically verified, Dutch policymakers remained in the dark regarding the extent and characteristics of the phenomenon.

As this research took place some years ago, there have obviously been further developments in the field. Parliamentary questions have been asked following the publication of the research report ${ }^{8}$ and the aforementioned custody institution has continued contributing to the visibility of the phenomenon. The so-called 'zakkenrollersteam' ('pickpocketing team') of the Amsterdam police has revealed pickpocketing exploitation structures as transnational organised crime, which has attracted considerable media attention. ${ }^{9}$ The visibility of trafficking in minors for exploitation in criminal activities has thus increased in the last couple of years.

Whether that has also led to a guarantee of victims' best interests is another matter. This form of trafficking remains under-researched, both in the Netherlands and beyond, and equally, not much research has been conducted on the treatment of victims in the criminal justice system or youth protection. This article aims to contribute to filling that gap by sharing some of Dutch frontline actors' experiences and dilemmas in identifying and dealing with minors who became victims of trafficking for exploitation in criminal activities. The obstacles they encountered are not unique for the Netherlands and, thus, the insights here may be relevant to child protection institutions in other countries.

7 I put Roma between quotation marks, as frontline actors use this as a container concept. Groups were considered 'Roma' without making further distinctions between, for example, Sinti or Ashkali, travellers, or itinerant groups from Central and Eastern Europe. Frontline actors could apply the label on the basis of self-identification by their clients, or through data on their country of birth, last names, ethnic or cultural appearance, or even 'looks' or 'gut feelings'.

8 See Tweede Kamer der Staten Generaal, Parliamentary questions (Appendix) 2017-2018, no.1589, 29 March 2018, retrieved 12 February 2021, https://zoek.officielebekend makingen.nl/ah-tk-20172018-1589.html.

9 See, for instance, M Wagemans, 'WNL Misdaadcollege: Rechercheur slaat alarm wanneer hij telkens dezelfde jonge zakkenrollers tegenkomt [Detective raises the alarm when he encounters the same young pickpockets every time]', WNL Misdaadcollege, 25 May 2020, retrieved 2 April 2021, https://wnl.tv/2020/05/25/wnl-misdaadcollegerechercheur-slaat-alarm-wanneer-hij-steeds-dezelfde-jonge-zakkenrollers-betrapt. 
In the following, I first elaborate on the research design and methods. Then I explain how the Dutch political context has influenced the identification of victims by frontline actors who, often unconsciously, look for ethnicised 'usual suspects' and victims. The next section elaborates on another narrowing of the perception on the phenomenon, namely the 'ideal victim' and its gendered consequences. After this, I go into the question why, more often than not, signals of trafficking for exploitation in criminal activities do not result in proper follow-ups and reactions. Finally, I draw conclusions from the research and discuss the need to focus on characteristics of the phenomenon of trafficking in minors for exploitation in criminal activities, rather than those of the victim.

\section{Methodology}

This explorative research revolved around two questions: first, what knowledge on the phenomenon already exists - the definition and characteristics of trafficking in minors for exploitation in criminal activities, perpetrator and victim profiles, the extent of the problem, its societal context, and best practices in approaching victims - and secondly, how frontline actors deal with the victims. ${ }^{10}$ We started with a systematic review of existing Dutch and international literature on trafficking in minors for exploitation in criminal activities and followed this with a qualitative, empirical study. We conducted 37 semi-structured interviews with frontline actors in four municipalities in the Netherlands, two of which were in the biggest cities, Amsterdam and Rotterdam, and the other two were smaller cities, Enschede and Ede.

We also aimed to research five cases that were as diverse as possible-in terms of the ethnicity, age, sex, and nationality of the victims; the possession or absence of a valid residence permit in the Netherlands; and in terms of whether the perpetrators were family members of the victims - in order to maximise the scope of different manifestations of the phenomenon. We first searched the public (online) legal archive. As mentioned, five cases had been successfully tried in court at the time, but they did not match our criteria of maximum diversity, as there was an overrepresentation of (supposedly) 'Roma' cases. Moreover, most were well-known among frontline actors, making spontaneous reflection difficult. We thus selected only one of these cases for further study and asked our frontline respondents for other cases. A complicating factor here was that policy choices targeting 'Roma' families, which had preceded the commissioning of

10 For the full research question and sub-questions, see Bos et al., pp. 10-11. 
the research, ${ }^{11}$ had clearly influenced frontline actors' perceptions: they looked at the phenomenon through a 'Roma lens' and conceptualised it as a 'Roma problem'. Hence, they could only come up with 'Roma' cases. We then decided to search the databases and archives of the Dutch police and the Board for cases that matched the legal definition of trafficking in minors, and in which the purpose had been exploitation in criminal activities. The five cases eventually selected consisted of three cases that frontline actors labelled as 'Roma' cases (of which two concerned non-residents, and one held Dutch residence status) and two cases in which the victims were Dutch nationals. The cases involved exploitation through shoplifting, transporting drugs, and burglary.

For each of these five selected cases, we studied the files and conducted semistructured interviews with at least two frontline actors involved in them. Where possible, we conducted (participant) observation during legal or child protection interventions, such as shadowing a legal guardian while intervening in a family and attending the court case of one of our case studies. We conducted additional observations in meetings of a law enforcement team that investigates child trafficking cases, and a legal entity concerned with the rapid settlement of penal cases. Finally, we validated our initial findings in two focus groups of 13 and 11 participants, respectively, consisting of frontline actors and policymakers.

\section{Recognising the Phenomenon: An ethnicised tunnel vision}

The phenomenon of trafficking in minors for exploitation in criminal activities is, compared to trafficking for sexual or labour exploitation, relatively unknown. In Europe, some insightful (mainly INGO and NGO) reports elaborate on it, ${ }^{12}$ but most are not based on academic research, nor aimed (solely) at knowledge production, limiting their academic value. There are very few in-depth academic

11 The research was commissioned following the 2011 national cooperation project, 'Tackling the Exploitation of Roma Children', a result of the call for action of several municipalities with a substantial number of Roma inhabitants. Although the commissioning body stipulated its explicit wish to extend the research beyond the Roma population, finding 'non-Roma' cases proved difficult due to these prior policy choices.

12 See, for instance, European Forum for Urban Security, Wandering Young People: The conditions for return, EFUS, Paris, January 2009; Z Vidra, K Baracsi and V Sebhelyi, Child Trafficking in Hungary: Sexual exploitation, forced begging and pickpocketing, Center for Policy Studies, Central European University, Budapest, 2015; and J Jovanović, "Vulnerability of Roma" and Anti-buman Trafficking Policies in Serbia: Recommendations to the National Policy Network, Center for Policy Studies, Central European University, Budapest, July 2015. 
studies on this issue. ${ }^{13}$ From this limited data, pickpocketing, forced begging, burglary, shoplifting, street vending (e.g. illegal cigarette vending), and drug trafficking (e.g. cutting cannabis leaves or transporting drugs over national borders) come to the fore as the most prevalent forms in Europe. Particularly concerning the first four forms of criminal activities, there is a strong emphasis in research on 'Roma' children and children from Central and East European countries as the primary victims of such exploitation.

We should, however, be sceptical about this 'ethnicisation' of the phenomenon. First of all, several of the aforementioned reports were part of European or national programmes specifically aimed at addressing the socio-economic exclusion of 'Roma groups' and, thus, politically and policy-inspired, rather than neutral investigations. Moreover, the victimisation of minors in this crime is described in the literature as linked to socio-economic disadvantages; living in segregated, impoverished, and crime-prone neighbourhoods; and being part of families in which parents are sick, use drugs or alcohol, are unemployed, or have migrated. ${ }^{14}$ There is no apparent reason to expect children from other ethnic groups living in similar circumstances to be less victimised. In other words: disproportionate victimisation is primarily linked to deprived living conditions, ${ }^{15}$ rather than having a certain ethnic background. Thirdly, Mary Christianakis insightfully points towards a Western, Eurocentric discourse by human rights organisations and media, pitching 'Roma childhoods' as endangered, dangerous, and 'other'. She shows how this can impact on interpretations of 'Roma' children's work, claiming that 'the parents, fellow Romani, and the Roma culture' are perceived as victimisers:

13 However, see, for instance, E Gjermeni et al., 'Trafficking of Children in Albania: Patterns of recruitment and reintegration', Child Abuse \& Neglect, vol. 32, issue 10, 2008, pp. 941-948, https://doi.org/10.1016/j.chiabu.2007.09.015; B Oude Breuil, 'Bienvenue Chez les Grands! Border-crossings of young migrant cigarette vendors in Marseille', in G Craig (ed.), Child Slavery Now. A contemporary reader, Policy Press, Bristol, 2010, pp. 189-202; B Lavaud-Legendre and O Peyroux, 'Mineur(e)s Nigérian(e)s et originaires des Balkans en situation de traite en France. Regards pluridisciplinaires sur les processus de l'asservissement et les échecs de la protection', Révue Européenne des Migrations Internationales, vol. 30, issue 1, 2014, pp. 105-130, https://doi.org/10.4000/ remi.6779.

14 For an overview of supposed characteristics of child victims of trafficking, see Bos et al., p. 35 .

15 We should, however, be careful not to over-emphasise the link between poverty and family dysfunction, on the one hand, and child trafficking on the other, or to assume a causal link here; after all, not every child coming from a poor or dysfunctional family gets trafficked. Presupposing causality here carries the danger of stigmatisation and criminalisation of poverty. 
'[The discourse claims that] their parents force them to beg, steal, engage in sexual exploitative acts, and enter into fraudulent marriages for slavery and servitude. Their childhoods are sacrificed for money by their caregivers, and therefore, their culture renders them incapable of their own self-actualization and participation in democracies. Their childhoods are, thus, dangerous and depart from the normative childhood set forth by the UN Convention of the Rights of the Child. ${ }^{16}$

If we follow her argument that this picture of 'Roma' children and their caregivers rather reflects the interests and biases of European organisations and media than the situation of 'Roma', we can conclude that there is no academic reason to suggest that the phenomenon of child trafficking for exploitation in criminal activities is a 'Roma phenomenon'. There is more reason to think that the existing idea among policymakers and social workers that it has resulted from an ethnic bias in research and policy that has become selfperpetuating.

Going back to the Dutch landscape, which is not detached from the European framework and its existing biases, we can conclude that there was a general lack of knowledge of the phenomenon at the time of the research. Frontline actors said they had not encountered cases of exploitation in criminal activities very often. The organisations they represented did not have any expertise on this phenomenon, apart from one or two employees who had encountered such cases. These employees oftentimes expressed feeling isolated in their organisations, and referred to their expertise as in the land of the blind, the one-eyed man is king'. Frontline actors of both law enforcement and child protection were unsure whether they would be able to recognise a case of trafficking in minors for exploitation in criminal activities if they encountered one.

This observation is not unique to the Netherlands; international studies show that frontline actors have trouble identifying minor victims of trafficking as they find the legal definitions difficult to apply to concrete cases. ${ }^{17}$ With victims

16 M Christianakis, 'Victimization and Vilification of Romani Children in Media and Human Rights Organizations Discourses', Social Inclusion, vol. 3, issue 5, 2015, pp. 48-63, p. 59, https://doi.org/10.17645/si.v3i5.250.

17 See, for instance, D R Hodge, 'Assisting Victims of Human Trafficking: Strategies to facilitate identification, exit from trafficking, and the restoration of wellness', Social Work, vol. 59, issue 2, 2014, pp. 111-118, https://doi.org/10.1093/sw/swu002; A Warria, $\mathrm{H}$ Nel and J Triegaardt, 'Challenges in Identification of Child Victims of Transnational Trafficking', Practice, vol. 27, issue 5, 2015, pp. 315-333, https://doi.or g/10.1080/09503153.2015.1039974. 
generally not self-identifying as such, and limited time for building trusting relationships with minors ${ }^{18}$ frontline actors struggle to recognise characteristics of exploitation in minors' narratives. Moreover, assumptions on what victims should ideally look like dissuade them from according victim status to minors who do not fit this ideal type. Especially with regard to itinerant or migrant minors, frontline actors may hold the opinion that these minors only came to the host country to profit from its social benefits, which can cloud their abilities to view them as victims. ${ }^{19}$

For itinerant 'Roma' groups, this observation takes a specific turn in the Dutch context. On the one hand, prior policy emphasis on combating exploitation within 'Roma' families sensitised frontline actors to linking exploitation in criminal activities to 'Roma' (or 'Central and East European groups', which can partly overlap with 'Roma'). When asked about exemplary cases of this form of trafficking, they showed an almost standard reaction: initial silence and a thoughtful frown, followed by: 'Oh, you mean Roma kids stealing and pickpocketing?' It was extremely difficult, if not impossible, to speak with Dutch frontline actors about this phenomenon in ethnically neutral terms. On the other hand, however, this increased visibility of itinerant 'Roma' as both perpetrators and victims did not always lead frontline actors to attribute the victim status to victimised minors, and thereby prevent the latter from being punished for the crimes they committed, as in the case described above. 'Roma' minors were thus recognised as 'usual' victims, but not always acknowledged as deserving victims.

18 See, for instance, P Rigby, 'Separated and Trafficked Children: The challenges for child protection professionals', Child Abuse Review, vol. 20, issue 5, 2011, pp. 329-334, https://doi.org/10.1002/car.1193; A West and D N Loeffler, 'Understanding Victim Resistance: An exploratory study of the experiences of service providers working with victims of child trafficking', Journal of Applied Research on Children: Informing Policy for Cbildren at Risk, vol. 6, issue 1, 2015, p. 17.

19 See, for instance, S J Terrio, 'New Barbarians at the Gates of Paris? Prosecuting undocumented minors in the juvenile court - The problem of the 'Petits Roumains', Anthropological Quarterly, vol. 81, issue 4, 2008, pp. 873-901, https://doi.org/10.1353/ anq.0.0032; V Nagy and B Oude Breuil, 'Mobility Rules. Migrant and drifters fare well (?) in post-welfare Europe', in F De Jong and M Boone (eds.), Overarching Views of Crime and Deviance - Rethinking the legacy of the Utrecht school, Eleven, The Hague, 2015, pp. 527-546; G Serughetti, 'Smuggled or Trafficked? Refugee or job seeker? Deconstructing rigid classifications by rethinking women's vulnerability', Anti-Trafficking Review, issue 11, 2018, pp. 16-35, https://doi.org/10.14197/atr.201218112. 
Frontline actors described their 'Roma' clients as 'difficult' and 'elusive', with distrust characterising the relationship. ${ }^{20}$ They held stereotypical perceptions on 'the Roma' as one unified group and did not distinguish between habits, culture, language, or residence status of different groups present in the Netherlands. The occurrence of exploitation of 'Roma' minors in criminal activities was attributed to (supposed) 'Roma' culture and 'their different norms and values'. As one respondent put it: 'These children are raised in an environment in which it is normal to go on a raid with your father, mother, or uncle'. ${ }^{21}$ Moreover, power relations within 'Roma' households were sometimes accepted as 'part of their culture' without further looking into eventual exploitative aspects of the relationship..$^{22}$ Frontline actors may then fail to further look into such cases, acknowledge these minors as victims, and approach them as such. ${ }^{23}$ This may explain the punitive attitude of frontline (supposedly expert) actors in the case of Milan at the beginning of this article and the label of 'little rascal' that was pinned to him.

A more punitive approach could befall not only 'Roma' victims of exploitation in criminal activities, but also their parents. This was illustrated through a case study on (native Dutch) mother Petra who had been apprehended by the police when leaving a supermarket with stolen goods in her bag. She was accompanied by her two children (including her 13-year-old daughter Anna) and the neighbours' daughter, and the police suspected Petra of having encouraged Anna to shoplift, and maybe the neighbours' daughter as well (according to a police report filed by the neighbour). When we learnt about this case and asked the Board workers whether this could be a case of exploitation in criminal activities, they reacted with surprise and irritation, commenting that 'this is not exactly a case in which parents encourage the children to go out and steal

20 See: Bos et al., pp. 82-84. This observation is not unique for the Netherlands; see on frontline and legal actors' negative feelings towards 'Roma' groups also Terrio (France); V Nagy, 'The Janus Face of Precarity-Securitisation of Roma mobility in the UK', Local Economy: The Journal of the Local Economy Policy Unit, vol. 33, issue 2, 2018, pp. 127-146, https://doi.org/10.1177/0269094218764117 (UK), and O Petintseva, “Entextualisation” Across Institutional Contexts: The impact of discourse in school reports on the juvenile justice trajectories of Roma youth', Youth Justice - An International Journal, vol. 19, issue 1, 2019, pp. 3-24, https://doi.org/10.1177/1473225419830786 (Belgium).

21 Bos et al., p. 60.

22 Ibid., p. 55

23 See also: S De Bus, O Petintseva and A Nuytiens, 'Roma-Meisjes op de Jeugdrechtbank: De professionele actoren binnen de jeugdbescherming aan het woord', Tijdschrift voor Jeugd en Kinderrechten, issue 2, 2017, pp. 84-107, http://hdl.handle.net/1854/LU8520408 . 
things'. ${ }^{24}$ However, in comparable cases of 'Roma' families, in which the role of the parents in the stealing behaviour was also not fully clear, the 'trafficking' label had been evoked. In trying to explain this, a Board supervisor referred to the different intervention instruments available in cases of Dutch families, on the one hand, and itinerant groups, on the other hand, who do not have registered addresses or for whom other administrative requirements are (still) not settled. The former case would be labelled as 'failed parenting', and Board workers would use youth protection intervention strategies (such as appointing a legal guardian). However, with mobile 'Roma' families, these measures would not succeed. ${ }^{25}$ Criminal law intervention was then considered the only means left to deal with the situation. The lack of effective child protection interventions for itinerant groups might thus reinforce already biased perceptions of 'Roma', through the pursuit of stigmatising criminal law interventions in cases that would otherwise have been dealt with through youth protection measures.

Therefore, in the general absence of proper expertise on the phenomenon of trafficking in minors for exploitation in criminal activities, and against the background of an ethnicised—or 'Roma-ised'—Dutch context, frontline actors have trouble recognising victimised minors. Itinerant 'Roma' groups, then, are seen as the usual suspects and as fitting the stereotypical victim profile. Although they might be identified as trafficking victims, this is not a guarantee for them to also be acknowledged as such, due to their stigmatisation and the reduction of 'Roma' childhoods as deviant, with children perceived as being in danger and, sometimes, dangerous. After all, the visibilised 'usual Roma victim' is far from an 'ideal victim'. I turn to this in the next section.

\section{Vulnerable Girls vs ‘Little Rascals’: A gendered approach?}

Several years ago, Marina and Leila, two French-speaking girls aged 15 and 17, were caught stealing jewellery from a villa in a residential area. There were strong indications that the girls could be connected to another burglary, too. When questioned by the police, Marina immediately admitted to the burglaries; Leila appealed to her right to remain silent. There were uncertainties about the girls'

24 According to them, the theft was an incident, Anna had acted on her own account, and her mother was probably unaware. However, the police file of the case indicated that the mother was aware of Anna putting things into her bag, and the public prosecutor expressed in her indictment her suspicions that the mother 'sent her children out to steal'-although without attaching the label of trafficking to it. See Bos et al., p. 56.

25 For similar observations on frontline actors' assessments of the failing of certain intervention modalities, due to the elusiveness of mobile 'Roma' communities, see De Bus, Petintseva and Nuytiens. 
identities, their legal guardians, and their residencies, which complicated the case, as the minors could not be sent home to their parents or guardians. Through an emergency hearing the girls were placed in custody and, soon after, in a (closed) youth facility. The treatment goal was to return them safely to their families in France, and to arrange the necessary help and support.

This case strongly resembles that of Milan and Krizstian: in both cases, the minors are not Dutch residents and 'visit' the Netherlands to commit burglaries. Both couples invoke questions about where and with whom they live, how they ended up in the Netherlands, and who they and their legal guardians are. In each of the cases, one of the minors has previous incidents in other countries and in both cases, when questioned, one of them appealed to their right to be silent, thereby complicating the resolution of the case. All four minors do not speak Dutch, and in both cases there are indications that they might be trafficked for exploitation in criminal activities - and at least one of the involved frontline actors raised the possibility of trafficking. Finally, in both cases the victims are recognised by frontline actors as part of 'Roma' or travelling Central or East European communities.

The ways the cases were understood and handled by professionals, however, were entirely different. Whereas Milan and Krizstián entered into a criminal procedure and were ultimately sentenced to four and six weeks in youth detention, Leila and Marina did not spend more than a few days in a cell- the time needed to appeal for an emergency hearing. They then entered into a civil procedure, aimed at their protection. A legal guardian was appointed and they were placed in a closed child protection facility. The goal of their treatment was to find their families and ensure they received support.

How can we explain the punitive approach towards the boys, especially considering their young age (12 and 14)? The concept of the 'ideal victim', who is also a deserving victim, can provide some further insight here. An ideal victim is 'a person or a category of individual who- when hit by crime-most readily [is] given the complete and legitimate status of being a victim'. ${ }^{26}$ We find the label of 'victim' deserved when the victim is considered weak and vulnerable, and thus unable to prevent the crime from happening. The victimiser, ideally, is someone unknown to the victim, a stranger who exerts his power over the victim; the victim is, therefore, not to blame for the crime befalling upon them. These two allegorical figures are gendered, as ideal victims are mostly women (and children), whereas ideal perpetrators are men. Even though Marina and Leila might not be (entirely) ideal victims - as discussed in the previous section, frontline actors

26 N Christie, 'The Ideal Victim', in E A Fattah (ed.), From Crime Policy to Victim Policy, Palgrave Macmillan, London, 1986, pp. 17-30, p. 18, https://doi.org/10.1007/9781-349-08305-3_2. 
often have negative perceptions towards 'Roma' clients, and in this case, they found the girls' story 'mendacious'-Marina and Leila do come closer to that ideal than the boys. Not innocent, but definitely (seen as) 'vulnerable'.

Their vulnerability pivoted around a few characteristics, emphasised in their files by respondents: first of all, Marina was pregnant and had a black eye that she could not convincingly explain. When placed in two different closed facilities, both girls longed to go home. In the Board files, the girls were repeatedly described as 'silent' and 'sad'. For the boys, this was quite different. The wording in the Board files at the beginning of this article is revealing: whereas the Board worker wrote that Marina 'was unable to withstand external manipulation', in Milan's file the focus was on the need for him to 'realise that he is not allowed to commit criminal offences'. Whereas Marina is pictured as a victim of circumstances, lacking agency, and a puppet on a string, Milan is primarily approached as an irresponsible individual who should learn to be accountable for his actions. Moreover, the police officer who handled the boys' case, a human trafficking expert, responded to my question whether now that he knew the boys were victims of trafficking he looked at their treatment and detention differently: 'No, not really. They did steal, and these boys were little rascals, you should have seen them when they were being questioned! They were tried and tested in dealing with us, and didn't give us any information.' It did not seem to occur to him that the fact that the boys knew how to deal with the police might not be a reflection of them being 'little rascals' but, rather, of being trained in how to behave in front of the police-which would strengthen the case for them being victims of (organised) trafficking. Nor did the resilient attitude of the girls, and their apparent agency-Marina, for example, escaped twice from the institution she was placed in, once by jumping out of a window, and once by taking a run during a shopping visit with a social worker, an escape prepared weeks in advance with someone's mobile phone she had secretly managed to get her hands on - seem to make a big difference in frontline actors' perceptions of them as the vulnerable, 'ideal victims'.

This finding of a possible gendered approach is confirmed by the interviews with frontline actors. Some of them mentioned that they find the possibility of girls as victims of trafficking just more obvious: it particularly makes a bell ring if it's a girl', ${ }^{27}$ and one frankly reflected that in cases of boys and girls that were otherwise comparable, she would 'intuitively' not find the boys similarly pitiable. Another (Board) frontline actor claimed that 'the judge perceives boys less easily as victims'; therefore, compared to boys, girls' chances for success were perceived as higher when advising the judge to apply a protection measure instead of a criminal justice intervention in their cases. De Bus, Petintseva

27 Bos et al., p. 61. 
and Nuytiens confirm the protective tendencies towards 'Roma' girls in youth justice: judges would either not follow up on crimes committed by 'Roma' girls at all (as the available forms of punishment or rehabilitation measures were not perceived to 'work' on this group), or they would place them in closed youth facilities. The reason behind the latter decision echoes the findings here: girls were seen as in need of protection from a living environment that was defined as dangerous to their wellbeing. ${ }^{28}$ As a result, frontline actors may indeed often have an 'ideal victim' in mind when assessing trafficking cases involving minors, and girls seem to fit that image better than boys-even when they are 'Roma' girls.

\section{From 'Soft Signals' to Decisive Action: A bumpy road}

The fact that cases of exploitation of minors in criminal activities did not often make it to court is, according to our research, not only due to not recognising and acknowledging cases as such. After all, in most studied cases, at some point in the investigation process - be it a criminal investigation by the police or the gathering of information by the Board-someone did mention suspicions of trafficking. Those indications, however, seem to 'get lost' somewhere along the line. Here, I explore some possible reasons for that and reflect on the value of the trafficking label.

Professionals in our research would sometimes choose to not (explicitly) label a case as trafficking, even if they did recognise it as such. This was, for example, Babette's case, a 13-year-old Dutch girl who was apprehended at Schiphol Airport for carrying a ball of cocaine in her body. There were clear indications that she had not independently chosen to do this, and the Board worker commented that she had recognised 'loverboy-like' characteristics ${ }^{29}$ to this case: Babette was in contact with her nine-years-older boyfriend ' 24 hours a day' via social media and was 'emotionally dependent' on him. She tried to protect him by not revealing his name, as 'she loved him'. Babette had no connections to peers her age, had a troubled relationship with her mother, and suffered from unresolved mourning of her deceased father — a list of indicators (stereo)typical

28 De Bus, Petintseva and Nuytiens, pp. 99-100.

29 'Loverboy' is a term for a recruitment strategy to engage young girls into prostitution and/or (here) into criminal activities that the so-called 'loverboy' is profiting from. It includes a young man making the girl fall in love with him and isolating her from her social support network. After making her emotionally dependent he would let her 'work' for him. See R Verwijs et al., Loverboys en Hun Slachtoffers. Inzicht in aard en omvang problematiek en in het aanbod aan hulpverlening en opvang, Verweij-Jonker Instituut, Utrecht, December 2011, https://www.verwey-jonker.nl/wp-content/uploads/2011/01/ SUMMARY.pdf. 
for a loverboy victim. However, that label—which would immediately trigger suspicion of a trafficking case-was not mentioned in the report. The Board worker did not use it because she did not want to influence the judge and 'stick to the facts'. Proper as this approach may be from the perspective of the neutral, informative role of the Board, it may also have contributed to the case not being recognised as a trafficking case. The Board worker did discuss her suspicions with her Royal Marechaussee ${ }^{30}$ colleague, with whom she cooperated in a team that retrieved unaccompanied minors at Schiphol. This colleague, however, did not follow up on her signal, as he reckoned there were not 'enough indications' to start a criminal investigation.

The case is similar to observations in other cases: in order to have suspicions of child trafficking further investigated, the initial signal needs to 'survive' its path through several institutions. In a scenario where frontline actors lack knowledge of the phenomenon (or feel insecure about it), a signal generally does not 'make it' to the subsequent institutions in the child protection chain. In some cases, like the above, that is surprising and might be a lapse of judgement. ${ }^{31} \mathrm{~A}$ signal being duly investigated, then, comes to depend on individual frontline actors not only recognising and acknowledging a case as exploitation in criminal activities, but also standing their ground, which generally they will not, considering their insecurity on this topic. Even though the small number of case studies makes it complex to draw generalised conclusions, the data suggests that this dependency on individual frontline actors' explicit and perseverant reporting of trafficking signals reinforces the aforementioned ethnic tunnel vision and its focus on ideal victims: where professionals have insufficient understanding of the phenomenon its characteristics, modus operandi, internal communication strategies, etc. - they fall back on the (supposed) characteristics of the victims. ${ }^{32}$ This focus seems to give them a (false) sense of security that this 'must be' a trafficking case, 'as this group is particularly prone to being linked to trafficking'.

30 The Dutch Royal Marechaussee is responsible for policing the borders; protecting persons, objects, and specific places; and fulfilling international and military police tasks. See 'Tasks of the Royal Netherlands Marechaussee', Ministry of Defence, retrieved 16 March 2021, https://english.defensie.nl/organisation/marechaussee/ tasks-of-the-royal-netherlands-marechaussee.

31 In this case, a criminal investigation did eventually start, but not until Babette's boyfriend reported himself to the police (for unknown reasons). He was tried for violating the opium law, assault of a minor, and human trafficking. See Bos et al., p. 135.

32 This was confirmed by a police officer and key respondent to this research, who asked the research team to provide him with a list of victim characteristics in order to make it easier on frontline actors to identify trafficking in minors for exploitation in criminal activities. We refused to do so for the obvious ethical reasons: such a list would, we argued, reinforce existing stereotypes and lead to biased targeting of certain (ethnic, as well as socio-economic) groups. 
There were three other reasons for frontline actors in our research to not label cases as trafficking, even though they thought they might qualify as such: the label's consequences are felt to oppose either organisational interests, the criminal justice interests (in other words: the investigative and prosecution aspects), or the best interests of the child. Concerning the organisation's interests: in the above case, the Royal Marechaussee worker commented that exploitation in criminal activities is probable in all cases of drug mules involving minors, and also in some cases involving adults. He said that labelling all these cases as human trafficking-and involving a human trafficking expert-would lead him to 'not have any drug cases left!'. Although expressed in a joking way, it does reveal an organisational interest to keep cases 'in their own hands', which could potentially result in underreporting human trafficking. He further explained that such labelling might not benefit the criminal justice interests of such cases either, since in human trafficking cases the burden of proof is 'considerably higher' than for other crimes. The evidence, thus, needs to be strong in order for the case to stand up in court.

Finally, frontline actors from the field of youth justice and child protection commented that labelling a case as trafficking might not be in the best interest of the child. Their observation is an important one, as it problematises the label itself, as well as its possible consequences. The argument, echoed in academic studies, ${ }^{33}$ is that in some cases legally qualifying as 'trafficking', applying that label pulls away from addressing structural (political, economic, and social) root causes, to the benefit of (often highly symbolic) punitive criminal justice reactions. This is particularly the case if the exploitation of the minor's criminal activities is a matter of 'family survival': when stealing is a way to make ends meet for families living in socioeconomically deprived conditions and where the proceeds (the illgotten booty) directly benefit the minors themselves. Prosecuting and giving jail terms to parents for trafficking their children can have severe consequences for the children, and may make their living conditions worse. A civil intervention, geared towards protecting the children, supporting parents in raising them, and structurally improving living conditions, would yield better results. Academic studies confirm that in cases of exploitation within the family, structural causes should be addressed and a mere criminal justice approach might, indeed, not be in the best interests of the child. ${ }^{34}$

33 See, for example: J O’Connell Davidson, 'Moving Children: Child trafficking, child migration, and child rights', Critical Social Policy, vol. 31, issue 3, 2011, pp. 454-477, https://doi.org/10.1177/0261018311405014.

Warria et al., p. 326. 


\section{Discussion and Conclusion}

This research has unveiled several problems in the identification of and approach to minors exploited in criminal activities. Most apparent is the general lack of knowledge about this form of trafficking. The characteristics of the phenomenon are not recognised by frontline actors, which leads them to focus on the 'usual suspects and victims', namely 'Roma'. This not only has a (further) stigmatising effect and reinforces the perception of 'Roma' childhoods as deviant and inferior, it also carries the risk of failing to recognise cases with another ethnic profile, which, as this research has shown, do exist. Moreover, these biased perceptions have translated into biased approaches. Whereas in cases concerning Dutch citizens and residents, frontline actors tended towards a youth justice and protective approach, addressing structural causes, and supporting parents in their parenting efforts, cases of 'Roma' families without stable residence in the country were seen as more difficult to effectively intervene in. Frontline actors were then more inclined to gear towards a criminal law approach, leading to (further) criminalisation of this group.

Frontline actors also demonstrated gendered biases: girls were more easily perceived as vulnerable and identified as victims, as well as referred to civil measures aimed at protecting them, compared to boys who would be subjected to criminal law interventions. In other words, the gendered perception of the 'ideal victim' results in a differential motivation to punish boys for the crimes they committed (and deny their victimhood) and to protect girls (and ignore their agency).

In the absence of sufficient knowledge on this form of trafficking in minors, frontline actors are inclined to overly focus on the characteristics of (potential) victims as a way to detect trafficking. Drawing lists of such characteristics, however, carries the risk of stereotyping certain ethnic, socioeconomically deprived, or in other ways 'deviant' groups, and distributing protection and punishment unequally. A more fruitful step forward, I argue, would be to focus on the characteristics of the phenomenon. Focusing on indicators such as minors not being allowed to benefit from the profits of their crimes; their position of (serious) dependency vis-à-vis the commissioning adult(s); and minors being obviously trained in dealing with the police or instructed on how to escape child protection institutions, might prevent professionals from disproportionally targeting certain groups and moralistically applying a Eurocentric measuring rod of 'good' and 'bad' childhoods. It might also prevent them from assessing and approaching possible trafficking cases on the basis of such opaque and culturally biased codes. 
Focusing on the characteristics of the phenomenon could also address frontline actors' legitimate concerns that applying the label of child trafficking may not (always) be in children's best interest, as it may distract from addressing families' varied socioeconomic situations. A focus on indicators of exploitation might help frontline actors make more transparent decisions on opting for a child protection measure, a criminal justice intervention, or both, provided that the indicators are not simplified into an 'either/or' choice (either they constitute trafficking, or they do not). Rather, they should be seen on a continuum. ${ }^{35}$ On one extreme, there are cases in which applying the trafficking label is very ambiguous-for example the above mentioned family survival-related stealing, which directly benefits the child and her family-while on the other extreme, there are cases in which exploitation and trafficking are more obvious - for example in cases of organised trafficking, where the profits are high, the agency of children is severely limited, and the children do not benefit from the crimes they commit; many shades of grey exist between these two extremes. Although such an approach would not give simple and clear-cut instructions for dealing with cases of trafficking in minors for exploitation in criminal activities, it does allow for more substantial, and from an ethnic and gender perspective more neutral considerations. If, moreover, these considerations are systematically shared and discussed among frontline professionals — both within and outside their organisations - it might, in time, expand the existing knowledge of the phenomenon. More empirical academic studies could further this goal.

These combined efforts might pave the way for a better identification of trafficking in minors for exploitation in criminal activities and guarantee that children's rights are respected, including the right not to be punished for crimes they were forced to commit. They might also help shift the focus to the root causes of the phenomenon and urge governments to address the economic, social, cultural, and gender inequalities at its heart, while keeping both the best interests of children and their agency in focus.

Brenda Oude Breuil is a senior lecturer at the Willem Pompe Institute for Criminal Law and Criminology, Utrecht University, and researcher in the Utrecht Centre for European Research into Family Law. Her research focuses on human trafficking, exploitation of minors, and other forms of exploitation in the global economy. As an anthropologist and cultural criminologist, she tries to understand the meaning of crime within its socioeconomic, political, and cultural context. She investigated the exploitation of minors in criminal activities for the Dutch government in 2016 and, most recently, co-edited Notes from Isolation: Global criminological perspectives on coronavirus pandemic (Eleven International Publishing, 2021). Email: b.oudebreuil@uu.nl

35 See for a similar argument O’Connell Davidson, p. 465. 